Eloise A. Brière

Eloise A. Brière is Professor of French and Francophone Literatures, Emerita-The University at Albany-SUNY.

Her research focuses on West Africa, the Caribbean and French North America.Email: ebriere@albany.edu

\section{Writing in Cameroon, the first hundred years}

\title{
Writing in Cameroon, the first hundred years
}

German, French and British colonization, the advent of Christian missions, the fight for independence and the subsequent neocolonial régime, impacted greatly on the literature produced in Cameroon between 1889 and 1989. These factors determined where writers studied, the gender of those who did study, the European languages they used, the purposes for which they wrote, as well as where they were published and read. Witnesses to the absurdity and abuses of several colonial masters as well as a variety of approaches to Christianity, Cameroonians' skepticism was evident in the oppositional stance that writers took in their fictional works. Early writers' attention to the status of women anticipated some of the themes women writers would later use to denounce the impact of tradition, patriarchy and poverty on the lives of women. Later fiction revealed the post-independence restrictions on Cameroon's progress towards freedom. In the process, Cameroonian writers made the French language theirs, adapting it to reflect the world they wrote about. Keywords: Cameroonian literature, Christianity, European languages, literature of opposition.

The modern literature of Cameroon might have been written in German had it not been for Europe's tribal war of 1914-18. Following the war the German colony was divided among the conquerors: a protectorate for France, covering four fifths of the territory and another for England along the Nigerian border. As these transitions suggest, the upheavals between 1885 and independence in 1960 were many in the territory, originally a pre-colonial multitude of ethnic jurisdictions at the time of Europe's trade in enslaved Africans and the arrival of British missionaries. The different names for the territory: Deutsch Kamerun, The Cameroons (British and French) at partition, and finally after independence and reunification: Cameroon (Anglophone) and Cameroun (Francophone) are reflected in the written literature produced by Cameroonians: the earliest works of the corpus-whether in German or French-are the first attempts by Cameroonians to fit into the colonizer's cultural and linguistic mold. This article deals only with francophone Cameroonian fiction writing until 1990 and considers its earlier German prototype. Gradually writing became anti-colonial as writers used the French language and narrative form to oppose the colonizer's mold which began to shatter after independence. But even before independence in 1960, the literature of Cameroon in French had already begun to stake out an enviable position on the African literary scene; it would continue to 
grow throughout the rest of the twentieth and twenty-first centuries. The distinctive nature and high quality of its early novels, engaged with social and political issues became its trademark, contrasting with works by the Negritude writers elsewhere in francophone Africa. Today it stands out among modern literatures as a place of dialogue for Cameroonians, both local and diasporic, involving not only writers, but also journalists, cinematographers, philosophers, historians, academics and social critics. ${ }^{1}$

\section{Before French...}

Before fictional narratives appeared in European-language books, narratives were created and transmitted by specialist orators throughout Cameroon's diverse ethnic groups. ${ }^{2}$ Writing slowly began to supplant the oral tradition during the nineteenth century as missionaries fanned out in the south coastal area, learning to write the Duala language to transmit the word of God. ${ }^{3}$ Thus in this region there was also an early tradition of writing in English due to missionary presence, while an adaptation of Arabic was used to the north; in the west Sultan Njoya devised a script for the Bamoun language in which he wrote the history of his people, the Bamoun (Zang Zang). Local writers such as Yoshua Dibundu used the newly written form of Duala to express religious sentiments as in his Besesedi bu Yehowa_the Praises of Jehova, 1896). Mission-sponsored publishing soon became a hallmark of Cameroonian literature; works in the Duala, Bassaa, Bulu, Bali and Ewondo languages continued to be published well into the twentieth century. With four editions $(1932,1939,1953$, 1989) Nnanga Kon by Jean-Louis Njemba Medou is the best known of these publications, a fictional text in Bulu, based on the arrival of the first white missionary in Bulu territory, the American pastor Adolphus Good, it won the London African Institute's Margaret Wrong Prize in 1932. ${ }^{4}$

German colonization and education produced a small literate elite whose expertise helped launch African studies in Germany. ${ }^{5}$ They shouldered the research which facilitated the work of Germany's first Africanists, mainly linguists and anthropologists. Members of this elite produced the earliest German language texts such as the collection of Cameroonian tales, Märchen aus Kamerun (1889) compiled by Njo Dibone, with Elli Meinhof, wife of the founder of African linguistics, Carl Meinhof (1857-1944). Njo Dibone served as Carl Meinhof's lektoren in Germany, teaching the famed linguist local languages and assisting him in his research. Written also in German, Josef Ekollo's autobiographical Wie ein Schwarzer das Land der Weissen ansieht (A Black Man's View of the Land of the White Man) provided an account of his impressions of Germany in 1908; a few years later Charles Atangana who taught Ewondo and Beti culture at the Colonial Institute in Hamburg from 1911 to 1913, wrote the Jaunde-Texte, in Ewondo, a compilation of letters, fables, tales and historical anecdotes which he then translated into German and published in 1919 
(Quinn 57). Sent to medical school in Germany in 1913, Dualla Misipo wrote the novel Der Junge aus Duala (The Youth from Douala, ca. 1930) a semi-autobiographical novel and a "substantial piece of writing" where racial discrimination not only in Germany but in South Africa and the USA are discussed in relation to the cultural divide encountered by the protagonist during his courtship of a German woman (Rosenhaft 35-6). ${ }^{6}$ For obvious reasons, Misipo and his half-Jewish German wife left Germany for France with their son in 1931 (see Pugach).

\section{A transition}

German influence waned progressively yet its remnants were clear in the works of a few contemporary writers. Alexander Kum'a N'dumbe III (1946-), prince of Douala's Bell royal family, like his forefathers was educated in Germany; he taught political science at Berlin's Free University, and produced a corpus of plays, short stories and poetry in German, Duala and French, before returning to Cameroon to teach at the University of Yaoundé (see Brière, "Théâtre camerounais"). Influenced by Brecht's theater, his works - first written in German, then translated into French-deal most often with social issues linked to the colonial and neo-colonial situation as in KafraBiatanga, Tragédie de l'Afrique (1973) and Amilcar Cabral ou La tempête en Guinée Bissao (1976) or post-colonial society and its failures as in Lisa, la putain de... (1976). ${ }^{7}$

Jean Ikelle Matiba (1936-84), who lived and worked in Germany, described the destructive German re-ordering of traditional life in Cette Afrique-là! (1963); in spite of its deracination of cultures and decimation of people-harsh, rigorous and uncompromising as it was-German colonization was seen to hold the key to westernization and progress. ${ }^{8}$ Ikelle Matiba's protagonist experiences the disappointment of the transition to French colonization following World War I, which marks the absurdity of the colonial enterprise as he undergoes yet another territorial and cultural dislocation (see Esuruoso and Koepsell 42; N'Gom). Like Kum'a N'dumbe before him, Patrice Nganang studied in Germany and occasionally writes scholarly articles in German; his first novel, completed in Hausen, Germany in 1999, marks the beginning of a distinct new turn in Cameroonian literature. His polyphonic Temps de chien won both the Marguerite Yourcenar Prize (2002) and the Grand Prix de la littérature d'Afrique noire (2003) after which it was translated into German.

\section{Then there was French...}

Cameroon's French language literature produced at the end of the colonial era stands out from that of other colonial territories by the number of texts by writers both in Cameroon and abroad, including Africa's first female writer, Marie-Claire Matip (Fandio 22-3). Early writers using French were, like Ikelle-Matiba, capable of bridging the divide between German and French colonization. Now it was France with its 'civilizing mission,' that set the norms for modernization: from now 
on writing in local languages would be outlawed (1921); missionary schools and Catholic seminaries alike began to produce a new francophone intellectual elite. ${ }^{9}$ Like their predecessors who used German, Isaac Moumié Etia (1889-1939) and Basile Juléat-Fouda (1934-) produced texts grounded in folklore. Moumié Etia published Les fables de Douala (Cameroun) en deux langues: français-douala (1929) and Juléat-Fouda published three tales in the literary review Lumina (1956-8). To legitimize French colonial presence the use of French was encouraged through literary contests sponsored by the French colonial administration's bi-monthly publication, La Gazette du Cameroun which included poetry, short stories and essays (1923 to 1939) (Bjornson 23). Winning a contest in 1935, Louis-Marie Pouka, born under German rule in 1910, would become an apologist for colonization through his poetry. Educated in French Catholic mission schools and seminaries and later in France, he worked first as an interpreter within the French colonial administration and later joined his country's administration after independence. As Pouka matured, his poetry, mostly written before 1950, distanced itself from a predictable imitation of French poets. Eight of the nine slim volumes of poems published between 1943 and 1971 were self-published; the collected works were published posthumously in 2010 by SOPECAM (Cameroon News and Printing Corporation). The upcoming generation of writers, graduates of the colony's first public secondary school (established after 1945) and studying in French universities, did not share Pouka's attachment to France. He was attacked in an open letter on February 20, 1954 in the Bulletin de l'AECF (Association of Cameroonian Students in France) authored by their spokesman, François Sengat-Kuo; the letter proclaimed that theirs would be a literature of social and political engagement (Bjornson 57). ${ }^{10}$ The following year Mongo Beti in "Afrique noire, littérature rose" launched a scathing attack on Camara Laye's portrayal of idyllic life in the French colony of Guinea in L'Enfant noir, because it skirted the reality of rampant colonial oppression (A.B. 137).

\section{Post-cards from Cameroon}

For nearly fifty years the positive accounts and carefully controlled views of colonized Cameroon orchestrated by the French colonial administration and the various mission societies at work in the territory were the only representations of the colony. Beginning in 1953 this view was shattered by the shocking, anti-colonial works of young politically committed writers studying in France. ${ }^{11}$ Within six years, starting in 1954, the passionate, highly talented Alexandre Awala-Biyidi (Mongo Beti) (1932-2001) and Ferdinand Oyono (1929-2010) as well as Benjamin Matip (1932-) had published a total of eight anti-colonial novels. François Sengat-Kuo (1931-97), Epanya Yondo (1930-90) and Jean-Paul Nyunai (1932-) turned to poetry to express anticolonial positions. Published in Paris, Cameroonian literature had come of age; its mordant satire portrayed exploited peasants, misguided missionaries, the hapless, sometimes sly, targets of their religious proselytism, and naïve adolescent 
misfits, ill-equipped by their French education to live in their own society. SengatKuo's Heures rouges and Fleurs de laterite (1954) memorialized those who died in the bloody anti-colonial 1945 Douala riots. A completely different image of Cameroon had reached the reading public.

Ferdinand Oyono's works portray naïve Africans who fall prey to colonial mirages. Une Vie de boy (1956) is the tragicomic story of a colonizer's houseboy whose innocence leads to his death from violence inflicted on him after discovering the inner workings of French colonial culture. Written in a similarly humorous vein and published the same year, Le Vieux Nègre et la médaille is a critique of the vieux nègre (old black man), who believed in France, was decorated for supporting the colonial administration and sending his sons to defend-and die in-France in World War II, yet who is thrown into prison by the colonial government, where he finally comes to realize the folly of supporting France. In the last of Oyono's novels, Chemins d'Europe (1960), French seminary education so changes the hapless picaro, Aki Barnabas, that his only desire is to find a way to leave his own country for Europe. Oyono entered Cameroon's diplomatic corps, never to return to writing, whereas Alexandre Biyidi-Awla (Mongo Beti) went on to write for 48 years.

Biyidi's Ville cruelle written under the name, Eza Boto (1953), began the writer's life-long opposition to injustice through his writings; the colonial web of dishonest Greek merchants and cocoa traders, unethical French loggers, and overly zealous missionaries foil the main character's attempts to become his own man. It was followed by Le Pauvre Christ de Bomba (1956), banned in France because of its unprecedented critique of colonization, narrated by a naïve houseboy who tells the story of a failed missionary, Rev. Drumont. The missionary unwittingly advances the colonizer's work, while at the same time his houseboy loses his innocence, and the women in training at the mission are sexually exploited. Continuing to portray the impact of colonization, Mission terminée (1957), is the story of the French-educated adolescent, Jean-Marie Medza who-having failed his final exams-is sent on a mission to his uncle's village where he confronts local customs, comes of age, and perceives the disarray created in his country by colonial rule. In Le Roi miraculé: Chronique des Essazam (1957), the strict imposition of Catholic monogamy on the ruler of the Essazam and his twenty two wives creates divisiveness and rains havoc on the Essazam people. Then Mongo Beti's silence lasted eleven years, it was followed by a series of novels: Perpétue ou l'habitude du Malheur (1974), Remember Ruben and the "Guillaume trilogy": La Ruine presque cocasse d'un polichinelle (1979), Les Deux mères de Guillaume Ismaël Dzewatama futur camionneur (1983), La Revanche de Guillaume Ismaël Dzewatama (1984), all set in Cameroon and featuring protagonists who are either victims of social and political injustice or who combat it. During this time, Beti rose to the pinnacle of the teaching profession in France, published a journal with his wife, Odile Biyidi, for 10 years: Peuples noirs, peuples africains and wrote numerous political 
essays and pamphlets. The first of these, Main Basse sur le Cameroun, autopsie d'une décolonisation (1972) remains a classic exposé of neocolonialism: it revealed the inner workings of Cameroon's neocolonial government and attacked President Ahmadou Ahidjo, the man France hand-picked to lead the newly independent country. The book was seized and banned by order of the French government at the request of Cameroon and nearly cost Beti his French citizenship. Upon retirement he returned to Cameroon, continued his activism, founded a bookstore, and published novels. Mongo Beti's œuvre culminated in 2000 with Branle-bas en noir et blanc. His sizable corpus has been the object of studies by a considerable number of critics around the world. Thomas Melone launched the now substantial body of contributions by Cameroonian literary critics of Mongo Beti's works, with Mongo Beti, L'homme et le destin (1972). ${ }^{12}$

\section{Writing about and by women}

The first two prose narratives published in Cameroon itself broke with the anticolonial literature produced by the Paris group: published in Yaoundé by the Librairie du Messager, they blazed a trail for the emancipation of, and writing by women. First among African women to engage in prose writing was Marie-Claire Matip (1938-). While male versions of early encounters with European education abound, her autobiographical novella, Ngonda (1956) is the first by a woman. Marie-Claire Matip offers a view of the challenges she faced because of school attendance: the difficult adaptation to the French colonial school, the aspirations it created and the resulting conflicts with traditions that governed the lives of her mother and grandmothers before her. Joseph Owono (1921-81) offered a forceful protest against the harm caused to women through polygamy, especially bride-price and child marriage, in his feminist novel Tante Bella (1959). ${ }^{13}$ Bella is exchanged like chattel from one husband to the next from the age of six until her death.

The novels that followed were neither anticolonial nor overtly political; they continued to draw attention to the situation of women in this period of cultural change: their lack of autonomy, their thirst for emancipation and their adaptation to modernity. Francis Bebey (1929-2001), a talented musician/performer who recorded many CDs of his music, creates strong unconventional female characters. In Le Fils d'Agatha Moudio (1967; Grand Prix Littéraire de l'Afrique noire, 1968) he offers a vision of love and marriage through Agatha's husband who accepts her mixed-race son, rather than to condemn the actions of his wife as tradition would have it. $\mathrm{La}$ Poupée Ashanti (1973) describes the power of Ghana's market women and the impact of changing times on their daughters. The first of a long line of Cameroonian novels set abroad, in Bebey's novel the Accra market women rise up against the corruption of the newly independent government.

The impact of postcolonial social change on women as well as marriage practices 
is at the heart of René Philombe's (1930-2001) Sola ma chérie (1966). In Perpétue et l'habitude du malheur (1974) by Mongo Beti, the narrator, returns home from concentration camp, and begins an investigation into the mysterious disappearance of his sister, Perpétue. Predictably more political, Beti's focus on women implicates both the postcolonial régime and traditional bride price practices in the exploitation and death of Perpétue. With greater access to education, writing offered women a means to analyze, express and respond to the pressures that limited their agency.

Shortly after the publication of the country's first collection of poetry by a woman, Poèmes sauvages et lamentations (1967) by Jeanne Ngo-Mai (1933-2008), the first novel was written by Thérèse Kuoh-Moukoury (1938-). Her influential father-like those of Matip and Ahiga-Ahanda (below) who were paramount chiefs_could not fail to see the value of education for his daughter. Jacques Kuoh-Moukoury (1909-2002) had risen through the ranks from colonial clerk to ambassador to France and penned an autobiographical novel, Doigts noirs (1963). ${ }^{14}$ Thérèse Kuoh-Moukoury's novel deals with issues facing an educated woman in a modern marriage. Completed a few years after Matip's 1956 novella, it did not appear until 1969. Despite her westernization and resulting autonomy, Kuoh Moukoury's protagonist in Rencontres essentielles $(1969,1973,1995)$ is nonetheless overshadowed by her sterility and adherence to the traditional belief that only motherhood will make her wholly a woman; this and other handicaps destroy her marriage. ${ }^{15}$

Within a few years more works by women appeared, such as Sociétés africaines et 'High Society': Petite ethnologie de l'arrivisme (1978) by Marie-Thérese Assiga-Ahanda (1941-2014); significantly, she followed in her father's footsteps as the first female to ascend to the throne of paramount Chief of the Ewondos. Her novel is also about a young western-educated couple who, upon their return from abroad, experience reverse cultural shock because the educated status of the protagonist's wife is not recognized, while both clash with the ruthless competition and corruption in the capital. La Brise du jour (1977), Lydie Dooh-Bunya's (1933-) only novel, is an autobiographical coming of age story that focuses on the inner conflict created by precepts of imported religion (Protestantism) and the romantic love the adolescent narrator feels for her cousin; at the same time it evokes social problems women of all ages face because of the tyranny of male domination (see Ekotto). ${ }^{16}$ Delphine Zanga Tsogo (1935-), trained as a nurse in France, eventually became head of Cameroon's Ministry of Social Affairs; she crafted two novels, cautionary tales about women damaged by men, yet self-sufficient enough to survive the conflict between modernity and the patriarchal forces that hem them in. L'Oiseau en cage (1983) is a coming of age story that illustrates the importance of female solidarity in combatting patriarchy. Like the protagonist in Ngonda, the novella written by Marie-Claire Matip, in this novel, Ekobo is one of the rare girls who attend school. Earning top grades, she begins to believe in her own value and agency only to have her growing freedom curtailed 
by her father who uses her educated status to secure a good bride price. She escapes the 'cage' of marriage through her friendship with other women, a crucial step that leads towards her emancipation. Like her, Dang and the other protagonists in Vies de femmes (1983) are victimized or abandoned by the men in their lives (see NfahAbbenyi 73-84). At this time the growth and development of literary criticism and analysis by university-trained Cameroonian women began to develop alongside increased creative writing by women. ${ }^{17}$

\section{A publisher of their own}

Continuing the pre-war tradition of mission-sponsored publication, a coalition of African and European Protestant churches founded Éditions CLE (Centre de Littérature Evangélique) shortly after Cameroon gained its independence from France. ${ }^{18}$ Its publications in the "Collection théologique" or in agricultural self-help books followed religious and social aims. However, German funding to CLE specifically for fiction writing made publication accessible to local writers; due to political unrest in Cameroon, cautious editorial choices and writers' self-censorship, a limited range of topics were addressed in literary works. However, within ten years of its founding CLE had become the largest publisher in French on the African continent, with 150 titles by 60 authors, 40 of whom were Cameroonian (Schaaf 86, 89) $\cdot{ }^{19}$ Among the first wave of CLE- published Cameroonians, René Philombe (ps. Philippe-Louis Ombede, 1930-2001), published four titles with CLE: Lettres de ma cambuse (1965; Mottard Prize of the French Academy), Sola ma chérie (1966), Un Sorcier blanc à Zangali (1970), and Histoires queue-de-chat (1971). Philombe also founded the writers' union, APEC, was its president for twenty years, and wrote the first Cameroonian history of his country's literature, Le Livre camerounais et ses auteurs $(1977,1984) \cdot{ }^{20}$ His creative writing focused on themes typical of Yaoundé writers during the Ahidjo régime; gone were the fiery indictments of mission Catholicism or protests against the abuses of colonial power launched in 1950s Paris. Philombe's published works dealt with the oppression of women, love relationships, bride-price and marriage, religious conflicts and superstitious beliefs in addition to the conflicts between modern and traditional lifestyles and the transition from one colonizer to the next. However two of Philombe's works dealing with political oppression remained unpublished; when those manuscripts were discovered he was incriminated as a subversive and incarcerated several times between 1960 and 1963. ${ }^{21}$ Africapolis and Choc Anti-choc were finally both published in 1978 by Semences Africaines, the publishing arm of Philombe's bookstore in Yaoundé, Librairie Semences Africaines (see Brière, "Littérature camerounaise"). Apolitical, Etienne Yanou's (1939-) L'homme-dieu de Bisso (1974), J. M. Nzouankeu's (1938-) Le souffle des ancêtres (1965), Joseph-Jules Mokto's (1945-) Ramitou mon étrangère (1971) and H. G. Ahanda Essomba's (1938-) Le Fruit défendu (1975), Patrice Etoundi-M'Balla's (1940-) Lettre ouverte soeur Marie-Pierre (1978) and works by many other authors 
of this period, dealt with obstacles arising from aspects of traditional precepts or taboos in conflict with new cultural elements. They were responding to the political climate while at the same time attempting to situate themselves within the context of independence. A number of CLE published writers continued the tradition of writing texts grounded in folklore, such as Michel Meva'a M'boutou's (1939-) Les Aventures de Koulou-la-Tortue (1972) or Mevoula Olinga's (1950-) La Guerre des Mekemeze (1980). Paul Dakeyo's (1948-) poetry is an exception to this rule, published in Paris, his collections Les Barbelés du matin (1973), Chant d'accusation (1976), Soweto! Soleils Fusillés (1977) and J'Appartiens au grand jour (1979) speak of the violence, brutality and injustice of neocolonial oppression in contemporary society (Bjornson 362). In his last two volumes, La Femme où j'ai mal (1989) and_Les Ombres de la nuit (1999), the solitary poet mourns a long-lost love (see Perri). Founded in 1980 by Dakeyo and others, Editions Silex published hundreds of titles in France before moving to Dakar where it is now known as Panafrika / Silex / Nouvelles du Sud. Today it publishes over a dozen titles per year, from creative works to scholarly publications from a wide range of authors (see "Paul Dakeyo").

\section{The last decade}

By the 1980s mastery of French was no longer a privilege of the educated few, but part of the cultural fabric of Cameroon. With this development, Cameroonian literature became more autonomous, empowering writers to deal with a wide array of topics and genres ranging from murder mysteries, and politically sensitive portrayals of Cameroon's corrupt political class and its ruthless pursuit of power, to patriarchy's violence against women; with — in between — the search for a coherent post-colonial identity and the adoption of new narrative strategies. ${ }^{22}$ Often writing abroad, this generation expressed its creativity with non-traditional narratives and language; many also used film and other media. Blaise N'Djehoya (1953-) wrote Le Nègre Potemkine (1988) a surrealistic novel that plays with language while paying homage to the expatriate American writer, Chester Himes. ${ }^{23}$ Its student-protagonists set out on a burlesque quest to right history by locating African soldiers who fought in France's World War I "Force Noire" battalion but whose service was never recognized. ${ }^{24}$ Also influenced by Himes, Simon Njami (1962-) whose detective story, Cercueil et cie (1985) takes as its starting point Chester Himes' Plan B, while his African Gigolo (1989) follows a marginal ladies' man whose adventures in France eventually lead to the humiliation of sexual impotence before he finally realizes that Cameroon is where he must go to find his identity (see King). Also residing in Paris, Yodi Karone (Alain Ndongo Ndiye, 1954-), based his novel Le Bal des Caimans (1980) on a trial that took place during the early years of the Ahidjo regime; in it he portrays the nightmarish world of the postcolonial government's prisons and questions a justice system that condemns both of his protagonists, the rebel and the priest, who had 
combatted poverty and despair, each in his own way; the rebel is executed, the priest imprisoned for life (Bishop 33-68). In Le Nègre de paille (1982; Grand Prix Littéraire $\mathrm{d}^{\prime}$ Afrique noire) Karone describes the difficult adaptation of a man newly returned from incarceration; lowlife criminality and corruption are central to Les Beaux gosses (1988) set in the slum neighborhoods of Ivory Coast's capital (Killam and Kerfoot 160). Bernard Nanga (1934-85) was a professor of philosophy at the University of Yaoundé until his untimely death. The retrospective story of his main character's idealization of French culture in La Trahison de Marianne (1984) is set in Paris' café culture where the protagonist's disillusionment with a mythical France progressively unfolds. Les Chauves-souris (1980) marked Nanga as a critic of the excesses and corruption of Cameroonian society: its protagonist Robert Bilanga, values money and power above all else; like those who inhabit the capital, he is rapacious and ruthless in his efforts to get ahead. With this scathing critique, Nanga joined the ranks of oppositional writers like Mongo Beti, but like René Philombe and others in Cameroon, he lived within reach of the forces of repression.

During this decade groundbreaking female perspectives were added to the literature of francophone Cameroon. While women writers like Evelyne Mpoudi Ngollé (1953-) Sous la cendre le feu (1990) or Philomène Bassek (1957-) La Tache de sang (1990) emerged during this time, it was however Werewere Liking (1950-) and Calixthe Beyala (1961-) who dominated the period. ${ }^{25}$ Beyala, who has been living in Europe since her late teens, is one of the few francophone writers to support herself through writing. She is perhaps the most productive and controversial of the Cameroonians abroad; winning prestigious literary prizes, accused of plagiarism, long ignored or undervalued by critics at home, she has amassed a considerable corpus, having published a novel nearly every two years since 1987 (Ngolwa). Her first novels, C'est le soleil qui m'a brûlée (1987) and Tu t'appeleras Tanga (1988) burst upon the literary scene, offering unprecedented perspectives of contemporary women's lives, indicting Cameroonian patriarchy. Using graphic language to depict sexual and psychological violence inflicted on her female protagonists, her use of narrative voice underscored the hopelessness of life in poverty for young marginalized women who yearn for love and a better life, but who are valued by their families solely for their commercial value (bride-price, prostitution). Ateba, the protagonist of $C^{\prime}$ est le soleil qui m'a brûlée, abandoned by her mother-a prostitute-is brought up by her aunt in the QG, a slum; the mother in Tu t'appeleras Tanga, shamelessly subjects Tanga to excision as a way of increasing her attractiveness to potential clients. Women in this nightmarish world have few options: Ateba is driven to commit a revenge murder while Tanga dies in prison (see Brière, Le Roman).

Writing from the Ivory Coast where she has lived since 1978, Werewere Liking (1950 -) was largely unschooled in western education but grounded in her own Bassa culture. A multi-talented artist, with an international reputation she founded the 
artistic cultural center Village Ki-Yi M'Bock where she is playwright-director. Author of a half-dozen published plays and two earlier novels, La Puissance d'Um (1980) and Orphée d'Afrique (1981), she continued to experiment with the integration of traditional elements of orality into the novel form with Elle sera de Jaspe et de corail: Journal d'une misovire (1983), a chant-roman (novel-song) (see Volet). A signature work in the form of a polyphonic journal, it is written by a misovire, Liking's coinage of a feminine form for misogynist; the misovire attempts to record her view of the coming of a new day in Lunaï, a degenerate, fictional African country. Her journal is interrupted by two men, incapable of leading Lunaï, whose dialogue fills the textual space and reprises the tired negritude debate opposing reason and emotion; the misovire uses shocking sexual images to describe their idiotic clinging to old concepts, suggesting that the power of regeneration lies with women (Diabate). L'Amour-cent-vies (1988) is also an experimental text that uses a blend of elements from traditional epics (eg. Soundjata) and the life of contemporary heroes (Ruben Um Nyobe) to build a powerful female figure, the grandmother Madjo, who — through ritual—saves her weak and spineless grandson, a figure of contemporary Cameroon, on the verge of committing suicide. He goes on to become a successful, respected artist. At the close of the 1980's Liking, and many of the above writers continued to hone their writing; whether published abroad or at home, new writers joined their ranks; their works further enriched and diversified the literature of Cameroon.

\section{Conclusion}

European colonization-first German, then French and British-obliged Cameroonians to submit to many changes; with the appropriation of their land, and their oral traditions largely dismissed, there was little choice but to adapt to the written means of expression imposed by their colonizers. Added to this, the multiplicity of Protestant and Catholic missionary endeavors, British, Swiss, German, French, American-each with its own cultural contribution and bias-could not fail to add new elements to Cameroon's ethnic cultural mix, while at the same time provoking skepticism to pronouncements and ideas from abroad. For instance Negritude sparked vigorous debates and publications starting with Mongo Beti's 1954 critique of Camara Laye's L'Enfant noir's Négritude view of French colonization (see discussion above); the debate continued with Thomas Melone's polemical De La Négritude dans la littérature négro-africaine (1962), followed by Marcien Towa's critique in Léopold Sédar Senghor: Négritude ou servitude (1971) and Stanislas Adotevi's Négritude et négrologues (1972). Christianity, Negritude or French influence, Cameroonian writers deftly questioned values whether Western or Cameroonian, old or new, as they sought to demystify the obstacles to progress and autonomy. The novels of the 1950s supplanted the earlier collections of folk tales and pro-French poetry, revealing for the first time the untenable nature of Cameroon's colonial universe; writers of the 1970s and 1980s 
critiqued patriarchy, neocolonialism, and corruption, while they experimented with form and some began living abroad. Women writers soon played a key role in shaping Cameroon's literature by questioning the practices that restrict not only women's lives and potential but also those of all Cameroonians. And finally, writers lost the reverence for the French language that once characterized their elders, imparting an unmistakably Cameroonian flavor to contemporary fiction. ${ }^{26}$

\section{Notes}

1. For the most complete and detailed history of Cameroonian literature see Bjornson's The African Quest for Freedom and Identity: Cameroonian Writing and the National Experience (1991); see also Ackad's Le Roman Camerounais et la critique (1985), Dehon's Le Roman camerounais d'expression française (1989), Joseph's contributions on Cameroon in Albert Gérard's African Language Literatures (1981) and European-Language Writing in Sub-Saharan Africa (1986), Patrice Kayo's Panorama de la littérature camerounaise (1972), David Ndachi-Tagne's Le Livre camerounais et ses auteurs (1986), volumes 1 and 2 of Notre Librairie and Rial's Littérature camerounaise de langue française (1972). Thérèse Baratte Eno Belinga's Ecrivains, cinéastes et artistes camerounais (1978) has a dated but useful bibliography containing biographical information. More recent are the 17 pages in Virginia Coulon's Bibliographie de littérature africaine (2005). For a discussion by Cameroonian scholars of Cameroonian literature and essays by writers both at home and abroad, see the volume Critical Perspectives on Cameroon Writing (2013) edited by Hansel Ndumbe Eyoh, Albert Azeyeh and Nalova Lyonga.

2. Among the Fang-Beti-Bulu group this specialist is the Mbomo-mvet, or player of the Mvet who recounts epic tales. Among the Bassa the specialist is the Hilun, or Hilun player and known as the Masomandala in the south coastal area (Kouo 12).

3. The first of these in 1846 were English (Alfred Saker) and Jamaican (Joseph Merrick) followed by the Basel Mission Society, starting in 1884, during the German period.

4. Despite the French injunction against publishing in local languages it was published in Bulu under American auspices at the Presbyterian Mission's Hasley Memorial Press of Elat in Ebolowa as was another immensely popular novel by Ondua Engulu, Dulu bon be Afrikara (1954) (Zang Zang). See also the 1989 translation by Jacques Fame Ndongo of Nnanga Kon.

5. The Seminar for Oriental Languages was founded in Berlin in 1887. In 1908 the Colonial Institute was founded in Hamburg (Rudin 209).

6. The authors speculate that Misipo may have been influenced by Harlem Renaissance writer James Weldon Johnson's Autobiography of a Colored Man (1912), noting similarities between the two texts. See also Joseph "Cameroon," European-Language Writing, 153-7.

7. The publication of his dissertation on the Nazi regime's plans for Africa had earlier been refused in Germany (see Esuruoso and Koepsell 42, see also Bjornson 443-8).

8. It was awarded Grand Prix de l'Afrique Noire in 1963 and published in German in 1966 as Adler und Lillie in Kamerun. Lebensbereicht eines Afrikaners.

9. This interdiction included writing in the Bamoun language, Mum, created and codified by Sultan Njoya who the French deposed and exiled to Yaoundé until his death (Zang Zang).

10. Sengat-Kuo, the fiery young poet, joined Cameroon's post-independence governments, which he later left, to play an instrumental role in Cameroon's opposition not long before his death (Dongmo).

11. They founded the Cameroonian Cultural Group (Cercle Cuturel Camerounais) in 1957 and published articles in its Revue Camerounaise aimed at analyzing the colonial situation, raising public awareness about independence and of the elite's role in the transition from colony to independent nation (Philombe 115).

12. For a sampling of critical works see: Fame N'dongo's L'Esthétique de Mongo Beti (1985), Ambroise Kom's Mongo Beti Parle (2002), André Djiffak's Mongo Beti: La Quête de la liberté(2000), Oscar Pfouma's Mongo Beti, le proscrit admirable (2003), Philippe Bissek's Mongo Beti à Yaoundé. 1991-2001 (2005), Auguste Owono-Kouma's Mongo Beti et la confrontation. Rôle et importance des personnages auxiliaires (2008), Cilas Kamedjio's Mongo Beti - Le combattant fatigué (2013), Claude Owono Zambo's Langue d'écriture, langue de résistance: Mongo Beti et les romans du retour (2014). For a different view of literary criticism in Cameroon, see Kom (29-36). 
13. It was based on an article he wrote for Etudes Camerounaises in 1953 on the dowry system and its impact on women (Mbaku 80).

14. Similarly Asiga-Ahanda's father, Charles Atangana (1884-1941), began his rise to power under the Germans as an interpreter, and wrote the Jaunde Text.

15. See the chapters on Matip and Kuoh-Moukoury in Toman's Contemporary Matriarchies in Cameroonian Francophone Literature: 'On est ensemble' (2008).

16. Dooh-Bunya now devotes most of her time to MODEFEN, an association she created to support and defend the rights of black women living in France.

17. Ninda (157-69) points out that Cameroon's male literary critics gave short shrift to works by women. Scholarship by female critics has flourished: Jeanne Dingome, Nalova Lyonga, Juliana Makuchi NfahAbbenyi, Cécile Dolisane, Frieda Ekotto, Alice Delphine Tang, and Marie-Rose Abomo-Maurin, have added much to the critical understanding of women's writing.

18. The creation of a College of Protestant Theology in Yaoundé (1962) and the Cameroon Biblical Society (SBC) set the stage for the founding of Éditions CLE. Its aim was to produce Christian literature (Schaaf).

19. For a listing of Cameroon publishers see Ndachi-Tagne ("Who's Who").

20. See Lambert (557-73) for a discussion of both the development of Éditions CLE and René Philombe and the first generation writers.

21. Writers in Cameroon still face the threat of incarceration as exemplified by the writer and activist, Enoh Meyomesse, imprisoned since 2011 (Mabanckou).

22. Many writers of this generation live in Paris. For an analysis of this phenomenon see Jules-Rosette.

23. See Killam and Kerfoot (211) for commentary on N'Djehoya's documentary Five Centuries of LonelinessLos Palenqueros of the Colombian Pacific (2001). Njami is a noted critic and curator of art.

24. For a discussion about Cameroonian writers who live in Paris, see Cazenave.

25. The 1990s ushered in many more works by women writers, see Manga.

26. The French language has benefited from the inclusion of new lexical items and structures from the various parts of the world where the language was implanted and adapted: Canada, North Africa, West and Equatorial Africa, the Caribbean, etc. On Cameroonian French see: Biloa; Mendo Ze; Nzesse.

\section{Works Cited}

A. B. (ps. Mongo Beti). "Afrique noire, littérature rose." Présence Africaine, 1-2 (1955): 137.

Ackad, Josette. Le Roman Camerounais et la critique. Paris: Silex 1985.

Adotevi, Stanislas. Négritude et négrologues. Yaoundé: CLE, 1972.

Assiga-Ahanda, Marie-Thérese. Sociétés africaines et 'High Society': Petite ethnologie de l'arrivisme. Libreville: Lion, 1978.

Belinga, Thérèse Baratte Eno. Ecrivains,cinéastes et artistes camerounais. Yaoundé: Centre d'Edition et de Production pour L'Enseignement et la Recherche, 1978.

Biloa, Edmond. La langue française au Cameroun. Berne: Peter Lang, 2003.

Bishop, Stephen L. Legal Oppositional Narrative. Lanham, MD: Lexington Books, 2008.

Bjornson, Richard. The African Quest for Freedom and Identity: Cameroonian Writing and the National Experience. Bloomington: Indiana U P, 1991.

Brière, Eloise A. Le Roman camerounais et ses discours. Paris: Nouvelles du Sud, 1993.

"Littérature camerounaise nouvelles tendances ou faux espoirs?" Peuples Noirs peuples africains 9 (1979): 69-80.

“Théâtre camerounais: Rideau fermé," Peuples noirs, Peuples africains, 19 (1981): 95-103.

Cazenave, Odile. Afrique sur seine, une nouvelle génération de romanciers africains à Paris Paris: L'Harmattan, 2003.

Coulon, Virginia. Bibliographie de littérature africaine. Paris : AUPELF/EDICEF, 2005.

Dehon, Claire. Le Roman camerounais d'expression française. Birmingham, AL: SUMMA Publications, 1989.

Diabate, Naminata. "Review of Werewere Liking's Elle sera de jaspe et de corail: Journal d'une misovire... " Words of Color. 5 Dec 2007. 26 Jan 2015. <https://naminandini.wordpress.com/2007/12/05/review-ofwerewere-likings-elle-sera-de-jaspe-et-de-corail-journal-d $\%$ E2\% $80 \% 99$ une-misovire $\%$ E2\% 80\% A6/>. 
Dongmo, Christophe. "Speechwriter, Minister and Opponent: François Sengat-Kuo and the Intricacies of Power." 11 Jan 2015. <http://www.camerounlink.net/news/?bnid=84\&ukat=\&sid=\&rub=\&kid $=45415 \&$ tid $=7 \&$ an_userid $=\&$ SessionID $=$ U3BA5OEX3KDXS5OHKWP6AZQGYC0HOF\&nid =0\&c at $=\&$ kat $=\&$ profile $=\&$ searchstring $=\& \mathrm{cl} 1=4 \& \mathrm{cl} 2=38 \& \mathrm{t} \_\mathrm{id}=\&$ wid $=2 \& \operatorname{sid} 1=\& \operatorname{code}=\& \mathrm{thisid}=\& \mathrm{th}$ is_id $=\&$ ville $=\&$ land $=>$.

Dooh-Bunya, Lydie. La Brise du jour. Yaoundé: Éditions CLE, 1977.

Ekotto, Frieda. "How to Reinvent your Body in Cameroonian Women's Writing." Thinking Bodies. Juliet Flower MacCannell, Laura Zakarin, eds. Stanford: Stanford U P, 1994, 149-55.

Esuruoso, Asoka and Philipp Khabo Koepsell, eds. Arriving in the Future: Stories of Home and Exile. Berlin: $\mathrm{GmbH}, 2014$.

Eyoh, Hansel Ndumbe; Albert Azeyeh, Nalova Lyonga, eds. Critical Perspectives on Cameroon Writing. Mankom, Bamenda, Cameroon: Language Research and Publications, CIG, 2013.

Fandio, Pierre. Les Lieux incertains du champ littéraire camerounais contemporain. Paris: L'Harmattan, 2012.

Ikelle Matiba, Jean. Cette Afrique-là! Paris: Présence Africaine, 1963. Adler und Lillie in Kamerun. Lebensbereicht eines Afrikaners. Tübingen: Erdmann, 1966.

Joseph, George. "Cameroon." African Language Literatures: An Introduction to the Literary History of SubSaharan Africa. Ed. Albert Gérard. London: Longman, 1981, 398.

. "Cameroon." European-Language Writing in Sub-Saharan Africa, Part I. Albert S. Gérard, ed. Amsterdam: John Benjamins, 1986, 153-7.

Jules-Rosette, Benetta. Black Paris: The African Writers' Landscape. Champaign, IL: Univ. of Illinois Press, 2000. Kayo, Patrice. Panorama de la littérature camerounaise. Yaoundé: CLE, 1972.

Killam, Douglas and Alicia Kerfoot. Student Encyclopedia of African Literature. Santa Barbara CA: ABC Clio (2008).

Kom, Ambroise. "Une Nécrologie: La critique littéraire au Cameroun." Critical Perspectives on Cameroonian Writing. Eds. Hansel N’Dumbe Eyoh, Albert Azeyeh, Nalova Lyonga. Mankom, Bamenda, Cameroon: Language Research and Publications, CIG, 2013, 29-36.

Kouo, Hélène Kingue Ntone. La Figure du héros dans les textes camerounais et français. Paris: L'Harmattan, 2009.

King, Adele. "Simon Njami/ Chester Himes." Towards a Transcultural Future: Literature and Society in a "Post"-colonial world. New York: Rodopi, 2004, 263-70.

Lambert, Fernando. "Cameroon." European-Language Writing in Sub-Saharan Africa, Part I. Ed. Albert S. Gérard. Amsterdam: John Benjamins, 1986, 557-74.

Mabanckou, Alain. "The Day of the Imprisoned Writer." The Guardian 14 Nov. 2014. 18 Jan 2015. < http:// www.theguardian.com/books/2014/nov/14/day-of-the-imprisoned-writer-dieudonne-enoh-meyomesse $>$.

Manga, Jacques Bessala. "Les amazones de la littérature camerounaise." 28 Dec 2013. 1 Feb 2015. < http:// www.langaa-rpcig.net/+Les-amazones-de-la-litterature +.html >.

Mbaku, John Mukum. Culture and Customs of Cameroon. Westport CT: Greenwood Publishing, 2005.

Medou, Jean-Louis Njemba. Nnanga Kon. Trans. Jacques Fame Ndongo. Yaoundé: Eds SOPECAM, 1989.

Melone, Thomas. De La Négritude dans la littérature négro-africaine. Paris: Présence Africaine, 1962.

Mendo Ze, Gervais. Une crise dans les crises. Le français en Afrique noire francophone: le cas du Cameroun. Paris: ABC, 1992.

Ndachi-Tagne, David. Le Livre camerounais et ses auteurs. Paris: L'Harmattan, 1986.

"Who's Who: L'Edition au Cameroun..." Littérature camerounaise, Notre Librairie 100 (janv-mars 1990): 60-61.

Nfah-Abbenyi, Juliana Makuchi. Gender in African Women's Writing. Bloomington: Indiana U P, 1997.

N'Gom, M’Bare. "Regards croisés: la reconstruction de '1'autre' dans 'Cette Afrique-là!' de Jean IkelleMatiba." Francofonía 9 (2000): 153-70.

Ngolwa, Moïse. "Disqualifications de l'homme et enjeux symbolique(s) dans l'œuvre romanesque de Calixthe Beyala." Ph.D. diss, Laval University, 2012.

Ninda, Joseph. "Femmes camerounaises en literature." La Littérature camerounaise depuis l'époque colonial. Yaoundé: P U Yaoundé 2004. 157-69.

Notre Librairie: La Littérature camerounaise 1 (1989).

Notre Librairie: La Littérature camerounaise 2 (1990). 
Nzesse, Ladislas. "Le Français au Cameroun: Appropriation et dialectalisation le cas de la presse écrite." 25 May 2015. <www.unice.fr/ILF-CNRS/ofcaf/19/Nzesse.pdf > .

Perri, Anne Cillon. "Les vieux brisquards : Fernando d'Alméida et Paul Dakeyo." Africultures. 29 Jan 2014. $<$ http://www.africultures.com/php/?nav=article\&no=3983\#sthash.b3QObt4h.dpuf $>$.

"Paul Dakeyo." Wikipedia. 25 Sept 2011. 29 Jan 2015. < http://fr.wikipedia.org/wiki/Paul_Dakeyo>.

Philombe, René. Le Livre Camerounais et ses auteurs. Yaoundé : Éditions Sémences africaines, 1977.

Pugach, Sara. Africa in Translation: A History of Colonial Linguistics in Germany and Beyond 1814-1945. Ann Arbor: U Michigan P, 2012.

Rial, Jacques. Littérature camerounaise de langue française. Paris: Payot, 1972.

Ricard, Alain. "Autonomie et universalité de la literature camerounaise." Llacan. 6 Jan 2015. < http://lacan. vjf.cnrs.fr/fichiers/Ricard/breme.pdf>.

Rosenhaft, Eve. "Schwarze Scmach and "Métissages contemporains" The Politics and Poetics of Mixed Marriages in a Refugee Family." Africa in Europe. Eve Rosenhaft, Robbie John Macvicar Aitken, eds. Liverpool: Liverpool UP, 2013, 34-54. 6 Jan 2015. < http://books.google.com/books?hl=fr\&lr=\&id=VnfBUS

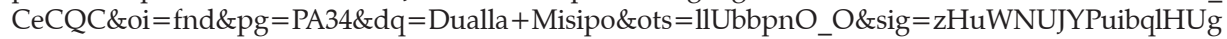
edwwrfzKuk\# $\mathrm{v}=$ onepage $\& \mathrm{q}=$ Dualla\% 20Misipo\& $\mathrm{f}=$ false $>$.

Rudin, Harry R. Germans in the Cameroons, 1884-1914: A Case Study in Modern Imperialism. New York: Greenwood Press, 1968.

Schaaf, Ype. Bible, Mission et Littérature écrite. Yaoundé: CLE, 2001.

Toman, Cheryl. Contemporary Matriarchies in Cameroonian Francophone Literature: 'On est ensemble'. Birmingham AL: Summa Publications, 2008.

Towa, Marcien. Léopold Sédar Senghor: Négritude ou servitude. Yaoundé: CLE, 1971.

Quinn, Frederick. In Search of Salt: Changes in Beti (Cameroon) Society, 1880-1960. New York, Oxford: Berghahn Books, 2006).

[Volet, J. M., ed.]. “Werewere Liking Gnepo.” 26 Jan 2015. < http://aflit.arts.uwa.edu.au/WerewereLiking. html>.

Zang Zang, Paul. Cohabitation des langues dans les médias au Cameroun 1884-1960. 6 Jan 2015. <http://www. sudlangues.sn/IMG/pdf/COHABITATION_DES_LANGUES_DANS_LES_1_.pdf > . 